\title{
9. CHARACTERIZATION OF DIAGENETIC FLUIDS OF THE UPPER JURASSIC-LOWER CRETACEOUS CARBONATE PLATFORM OF THE GALICIA MARGIN AT OCEAN DRILLING PROGRAM SITE 639: EVIDENCE FOR DOLOMITIZATION BY HYPERSALINE BRINES ${ }^{1}$
}

\author{
Janet A. Haggerty, Department of Geosciences, University of Tulsa, Tulsa, Oklahoma \\ and \\ Michael P. Smith, Amoco Production Company, Tulsa Research Center, Tulsa, Oklahoma
}

\begin{abstract}
Site 639, drilled during Leg 103 of the Ocean Drilling Program, penetrated an Upper Jurassic to Lower Cretaceous carbonate platform on a tilted fault block along the Galicia margin off the northwest Iberian Peninsula. The carbonate platform is composed primarily of a sequence of dolomite overlying limestone. Samples were analyzed for mineral chemistry, stable isotope geochemistry, fluid inclusion microthermometry, and volatile contents and by dolomite pyrolysis mass spectrometry for trace sulfate minerals. The dolomite recovered from the Galicia margin at Site 639 formed during shallow burial from sulfate-bearing, hypersaline brines at slightly elevated temperatures. The light oxygen isotopic signatures of the dolomite are interpreted as the result of the evaporative loop and slightly elevated temperatures during dolomite formation or from reequilibration at higher temperatures during deeper burial. The hypersalinity is interpreted to be associated with a nearby, shallow restricted basin that formed during rifting of the Iberian margin from Newfoundland. The dolomitization of the platform is therefore a by-product of the rifting.
\end{abstract}

\section{INTRODUCTION}

A transect of five sites (Sites 637-641) was drilled during Ocean Drilling Program (ODP) Leg 103 on the Galicia margin with the objective of determining the tectonic evolution of this passive margin. Drilling at Site 639 recovered dolomite and limestone from a carbonate platform. Site 639 is on the seaward edge of a tilted fault block, in a water depth of approximately $4740 \mathrm{~m}$. A series of fault blocks formed as a result of rifting of the Galicia margin from Newfoundland during the development of the modern North Atlantic. The blocks appear as a sequence of ascending steps from the eastern North Atlantic Basin up the outer portion of the Galicia margin on the northern Iberian continental margin. The geologic setting is summarized in the "Site 639" chapter of the Initial Reports volume (Boillot, Winterer, et al., 1987).

The distribution of the Site 639 holes is across $800 \mathrm{~m}$, from the easternmost hole (639A), at a water depth of $4720 \mathrm{~m}$, to the westernmost hole (639F), at a water depth of $4754 \mathrm{~m}$ (Fig. 1). This series of holes penetrated an Upper Jurassic to Lower Cretaceous carbonate platform composed predominantly of dolomite overlying limestone (lithologic Units IV and V, respectively; Fig. 1; see "Site 639" chapter; Boillot, Winterer, et al., 1987). Difficult drilling conditions in the fractured and brecciated dolomite resulted in the drill pipe usually becoming stuck in the hole before reaching the limestone section of the carbonate platform; Hole 639D was the only hole that penetrated the limestone. The carbonate platform is overlain by Valanginian marlstone (lithologic Unit III), unfossiliferous brown clay (lithologic Unit II), and middle Pliocene to Pleistocene pelagic sediments (lithologic Unit I) (Fig. 1). The contact between the Unit III Valanginian marlstone and the Unit IV dolomite was not recovered. The strata from Units III, IV, and V dip east and crop out on the western-facing submarine erosion surface of the fault block. Neogene pelagic ooze (related to Unit I) onlaps this western side of the fault block. These strata record the evolution of

\footnotetext{
${ }^{1}$ Boillot, G., Winterer, E. L., et al., 1988. Proc. ODP, Sci. Results, 103: College Station, TX (Ocean Drilling Program).
}

the Galicia margin in the region of a shallow-water carbonate platform that subsided during the syn-rift and post-rift stages.

This geochemical study was undertaken to identify the diagenetic fluids that dolomitized the carbonate platform. Samples were analyzed for mineral chemistry, stable isotope geochemistry, fluid inclusion homogenization temperatures, and fluid inclusion volatile contents. Samples were also analyzed for trace sulfate minerals using dolomite pyrolysis mass spectrometry. These data indicate that the dolomite formed during shallow burial from hypersaline brines at temperatures elevated above surface conditions.

\section{METHODS}

The dolomite and limestone (Units IV and V) as well as the distribution of fracture fills, veins, and textural changes in these units were surveyed, and representative samples were selected aboard ship. Mineralogy of the host rock, fracture fills, and veins were identified by X-ray diffraction using a Norelco diffractometer with a high-energy, Ni-filtered $\mathrm{Cu}-\mathrm{K}_{\alpha}$ source.

Electron microprobe analysis was used to determine variations in the chemical composition of the samples. For analysis of dolomite and calcite, polished thin sections were coated with silver following the method of Smith (1986) to inhibit thermal decomposition of the carbonates during electron bombardment. An ARL five-spectrometer electron microprobe with a $1-\mu \mathrm{m}$ focused beam was operated at an accelerating potential of $20 \mathrm{kV}$ and a sample current of $20 \mathrm{nA}$ for dolomite analysis. A sample current of $10 \mathrm{nA}$ was used for calcite analysis. For dolomite analysis, counting times on the peak, as well as on both the high and low background sides of the peak, were $10 \mathrm{~s}$ for $\mathrm{Ca}$ and $\mathrm{Mg}, 300 \mathrm{~s}$ for $\mathrm{S}$ and $\mathrm{Na}$, and $310 \mathrm{~s}$ for $\mathrm{Fe}, \mathrm{Mn}$, and $\mathrm{Sr}$. Calcite analysis counting times were $60 \mathrm{~s}$ for $\mathrm{Ca}$ and $\mathrm{Mg}, 300 \mathrm{~s}$ for $\mathrm{S}$ and $\mathrm{Na}$, and $360 \mathrm{~s}$ for $\mathrm{Fe}, \mathrm{Mn}$, and Sr. In addition, each analysis reported in Table 1 is an average of two analyses of different parts of the sample.

Preparation of the samples for microprobe analysis and the electron microprobe operating conditions used in this study differ from most microprobe studies of carbonates for several reasons:

1. Coating carbonates with silver rather than carbon permits the use of higher sample currents, a focused beam, and longer counting times without thermally decomposing the sample.

2 . The $1-\mu \mathrm{m}$ focused beam is more than an order of magnitude smaller than the diffuse beam used in other carbonate studies; therefore, spatial resolution is enhanced. 


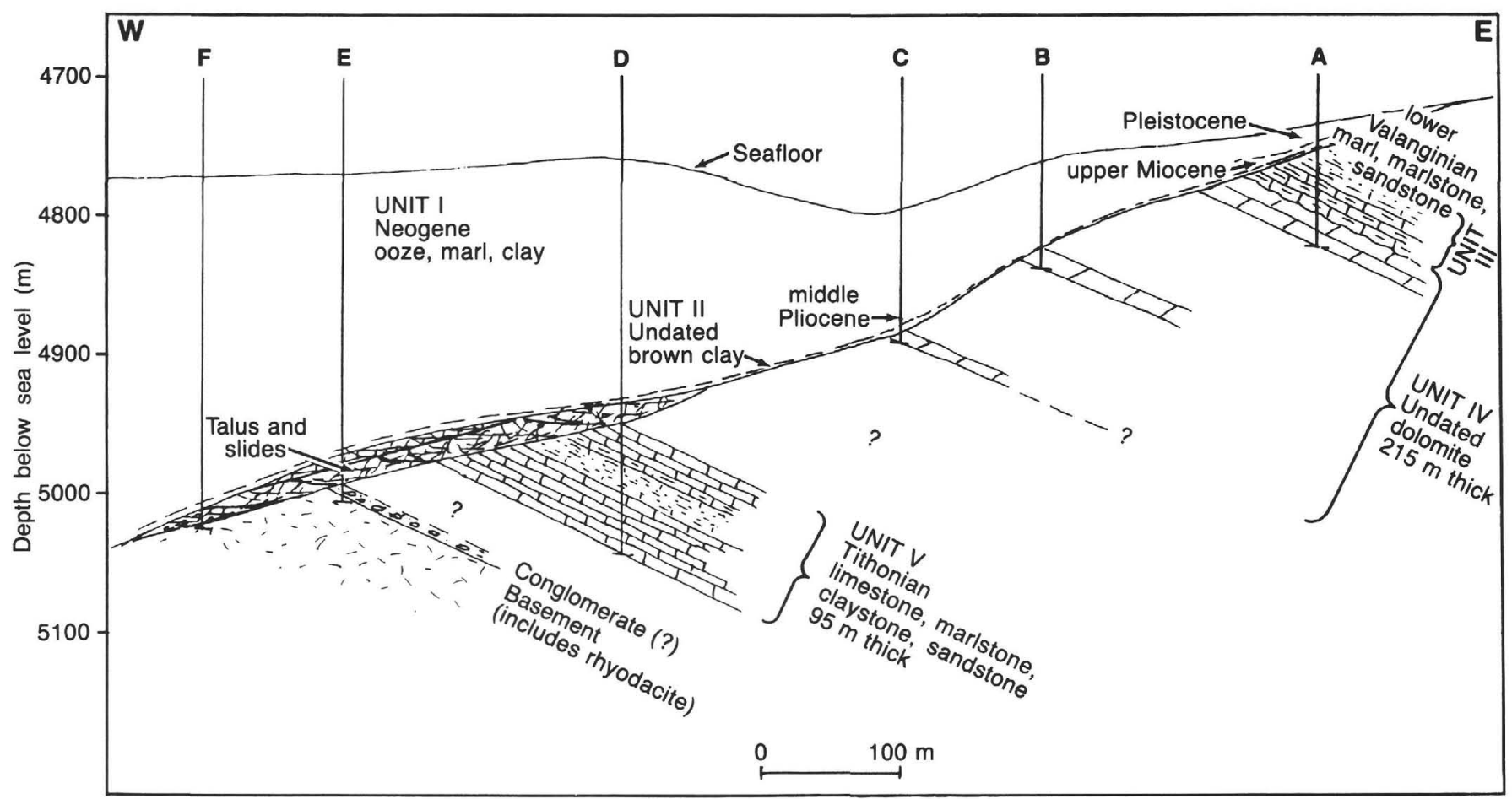

Figure 1. Geologic cross section, showing the position of six holes drilled at Site 639 and the lithologic units (from Boillot, Winterer, et al., 1987).

3. Extremely long counting times are used for trace element analyses-at least 5 min on the peak and 10 min total on the background. These long counting times lower the detection limits for trace elements in carbonate minerals.

4. Sr- $\mathrm{L}_{\alpha}$ is analyzed using a thallium acid phthalate (TAP) crystal rather than a pentaerythritol (PET) crystal. The Sr- $\mathrm{L}_{\alpha}$ peak on a TAP crystal occurs near the lower limit of the wavelength spectrometer, which provides maximum intensity of $\mathrm{X}$-rays and the lowest detection limits. The Sr- $\mathrm{L}_{\alpha}$ peak on the PET crystal occurs on the upper limit of the wavelength spectrometer, which causes the intensity of the X-rays to be extremely attenuated.

Microprobe detection limits for each element were calculated using three times the square root of the background counts of the element analyzed. The detection limits for elements analyzed in dolomite are 120 ppm Ca, 350 ppm Mg, 40 ppm Fe, 40 ppm Mn, 90 ppm Na, 150 ppm Sr, and $20 \mathrm{ppm} \mathrm{S}$. The detection limits for elements analyzed in calcite are $70 \mathrm{ppm} \mathrm{Ca}, 150$ ppm Mg, 50 ppm Fe, 50 ppm Mn, 70 ppm Na, 150 ppm $\mathrm{Sr}$, and $20 \mathrm{ppm} \mathrm{S}$.

Fifty samples of dolomite and calcite were analyzed for carbon and oxygen isotopic composition. Samples of crystals within veins, as well as the host rock, were vacuum roasted at $300^{\circ} \mathrm{C}$ for $1 \mathrm{hr}$ to remove volatile components. Carbon dioxide was evolved from 10-15 mg of carbonate sediment reacted with $100 \%$ phosphoric acid and extracted for isotopic analysis following the procedure outlined by McCrea (1950). The carbon dioxide gas sample was analyzed on a Finnigan MAT 251; analyses are reported relative to PDB standard. Analytical error was no greater than $\pm 0.2 \%$.

Chips of dolomite and calcite were used for fluid inclusion microthermometry, identification of volatile contents within inclusions, and dolomite pyrolysis mass spectrometry. Samples were checked petrographically for the presence of two-phase, primary fluid inclusions.

Standard techniques discussed in Roedder (1984) and Shepherd et al. (1985) were used to determine homogenization temperatures of fluid inclusions on a USGS-type heating and freezing stage.

Fluid inclusion mass spectrometry and dolomite pyrolysis mass spectrometry are experimental techniques under development by one of the authors (Smith). Mass spectrometric determination of the gases in individual fluid inclusions was accomplished following the technique outlined in Barker and Smith (1986).

Dolomite pyrolysis mass spectrometry was used to show the presence of trace quantities of sulfate minerals. Pyrolysis mass spectrometry was conducted on 25 - to $100-\mu \mathrm{g}$ samples selected by using a binocular microscope. After triple washing in $100 \mathrm{~mL}$ of distilled and deionized water for more than $1 \mathrm{hr}$, an air-dried sample was carefully loaded into a ceramic sample tube for pyrolysis. The sample tube was bolted directly to the mass spectrometer vacuum system and evacuated. Gases released during pyrolysis were dynamically pumped with a turbo-molecular pump through two mass spectrometers to monitor carbon dioxide and sulfur dioxide from room temperature to $1400^{\circ} \mathrm{C}$. Frequent pyrolysis runs of blank sample tubes or sample tubes containing 25 to $100 \mu \mathrm{g}$ of triple-washed quartz displayed no sulfur dioxide release. Sulfate minerals decompose and release sulfur dioxide at characteristic temperatures. The great sensitivity of the mass spectrometer allows extremely small amounts of sulfate minerals to be identified by this technique. Sulfide minerals, such as pyrite, do not contain oxygen and, therefore, do not release sulfur dioxide upon heating in vacuum.

\section{RESULTS AND DISCUSSION}

\section{Oxidation State of the Dolomitizing Fluids}

Table 1 lists the description, mineralogy, sub-bottom depth, stable isotopic composition, and results from electron microprobe analysis for all of the samples in this study. All of the dolomites analyzed are nonferroan. These dolomites are low in iron and manganese, as is typical of massive dolomite (Weber, 1964; Mattes and Mountjoy, 1980; Veizer, 1983).

The dolomite samples from ODP Site 639 are texturally and chemically different from other continental margin dolomites discussed by Baker and Burns (1985) that were recovered at 10 Deep Sea Drilling Project (DSDP) sites scattered around the world. The DSDP continental margin dolomites are associated with Miocene through Holocene organic-rich sediments. They chiefly occur as isolated lenses and rhombohedra that constitute, at most, $4.7 \mathrm{wt} \%$ of the whole rock; therefore, they are not massive dolomites. In addition, the DSDP continental margin dolomites contain significantly more iron and manganese and have a negative carbon isotopic signature, unlike the massive Galicia margin dolomite.

Microprobe analysis detected sulfur in most of the samples (Table 1). We suspected that the dolomite might contain sulfate 
Table 1. Description, mineralogy, stable isotopic composition, and elemental concentrations from ODP Site 639 samples.

\begin{tabular}{|c|c|c|c|c|c|c|c|c|c|c|c|c|c|}
\hline $\begin{array}{c}\text { Sample } \\
\text { interval }(\mathrm{cm})\end{array}$ & $\begin{array}{l}\text { Depth } \\
\text { (mbsf) }\end{array}$ & Description & Mineralogy & $\begin{array}{l}\text { Lithologic } \\
\text { unit }^{\mathrm{a}}\end{array}$ & $\begin{array}{c}\delta^{13} \mathrm{C} \\
(\% 0)\end{array}$ & $\begin{array}{c}\delta^{18} \mathrm{O} \\
(\% 0)\end{array}$ & $\mathrm{Fe}$ & $\mathrm{Mn}$ & $\begin{array}{l}\mathrm{S} \\
\text { (con }\end{array}$ & $\begin{array}{l}\mathrm{Sr} \\
\text { entratio }\end{array}$ & $\begin{array}{l}\mathrm{Na} \\
\mathrm{ns} \text { in pp }\end{array}$ & $m)^{b^{\mathrm{Mg}}}$ & $\mathrm{Ca}$ \\
\hline \multicolumn{14}{|l|}{ Hole 639A: } \\
\hline $6 \mathrm{R}-2,83-85$ & 43.93 & Marl & Calcite & III & +1.3 & -0.8 & 630 & 140 & 80 & 370 & 70 & 3900 & 390,000 \\
\hline $6 \mathrm{R}-2,138-139$ & 44.48 & Brown vein & Calcite & III & +1.6 & -1.8 & 170 & $\mathrm{BD}$ & 40 & 470 & $\mathrm{BD}$ & 3300 & 402,000 \\
\hline $8 \mathrm{R}, \mathrm{CC}(6-11)$ & 70.30 & Host & Dolomite & IV & +1.4 & -9.4 & 190 & 70 & 250 & 750 & 190 & 115,000 & 238,000 \\
\hline $9 \mathrm{R}-1,11-15$ & 70.51 & Host & Dolomite & IV & +1.9 & -8.0 & $\mathrm{BD}$ & 40 & 40 & 380 & 90 & 130,200 & 218,000 \\
\hline $9 \mathrm{R}-1,87-90$ & 71.27 & Host & Dolomite & IV & +1.2 & -11.3 & 60 & $\mathrm{BD}$ & 40 & 330 & $\mathrm{BD}$ & 128,600 & 220,000 \\
\hline $9 \mathrm{R}-1,94-98$ & 71.34 & White vein & Dolomite & IV & +1.6 & -11.2 & $\mathrm{BD}$ & $\mathrm{BD}$ & 50 & 510 & 90 & 127,600 & 219,000 \\
\hline & 71.34 & Host & Dolomite & IV & +1.6 & -11.1 & $\mathrm{BD}$ & 70 & 30 & 230 & $\mathrm{BD}$ & 128,800 & 221,000 \\
\hline $10 \mathrm{R}-1,32-35$ & 80.42 & Host & Dolomite & IV & +1.6 & -11.1 & 50 & 60 & 50 & 370 & 140 & 127,500 & 223,000 \\
\hline $10 \mathrm{R}-1,47-49$ & 80.57 & Host & Dolomite & IV & +1.5 & -10.8 & 40 & 40 & 20 & 360 & $\mathrm{BD}$ & 129,400 & 224,000 \\
\hline $10 \mathrm{R}-2,16-19$ & 81.76 & Detrital silt & Dolomite & IV & +2.4 & -4.1 & 90 & 50 & 80 & 540 & 200 & 121,200 & 230,000 \\
\hline & 81.76 & Dark brown infill & Dolomite & IV & +1.5 & -10.9 & 130 & $\mathrm{BD}$ & 170 & 560 & 180 & 120,000 & 235,000 \\
\hline & 81.76 & Host & Dolomite & IV & +1.5 & -10.9 & 50 & $\mathrm{BD}$ & 50 & 420 & 120 & 127,500 & 220,000 \\
\hline & 81.76 & White vein & Dolomite & IV & +1.4 & -10.9 & 40 & 50 & $\mathrm{BD}$ & 260 & $\mathrm{BD}$ & 130,000 & 223,000 \\
\hline $10 \mathrm{R}-2,48-50$ & 82.08 & Host & Dolomite & IV & +1.6 & -9.7 & 110 & 40 & 50 & 430 & $\mathrm{BD}$ & 129,500 & 230,000 \\
\hline \multicolumn{14}{|l|}{ Hole 639B: } \\
\hline $2 \mathrm{R}-1,35-37$ & 63.85 & Dark brown host & Dolomite & IV & +1.6 & -9.8 & 50 & $\mathrm{BD}$ & 230 & 530 & 220 & 117,500 & 238,000 \\
\hline \multirow[t]{2}{*}{$3 \mathrm{R}-1,46-51$} & 66.96 & Brown sugary crystals & Dolomite & IV & +1.8 & -5.8 & $\mathrm{BD}$ & $\mathrm{BD}$ & 210 & 670 & 160 & 117,000 & 234,000 \\
\hline & 66.96 & Dark brown host & Dolomite & IV & +1.6 & -9.8 & 60 & $\mathrm{BD}$ & 130 & 280 & $\mathrm{BD}$ & 120,800 & 232,000 \\
\hline $3 \mathrm{R}, \mathrm{CC}(0-4)$ & 75.90 & Vein & Dolomite & IV & +1.2 & -4.5 & $\mathrm{BD}$ & $\mathrm{BD}$ & 120 & 550 & 190 & 112,700 & 243,000 \\
\hline $4 \mathrm{R}-1,35-37$ & 76.35 & Light brown crystals from vug & Dolomite & IV & +1.6 & -9.8 & $\mathrm{BD}$ & $\mathrm{BD}$ & 30 & 440 & 110 & 126,200 & 220,000 \\
\hline \multirow[t]{3}{*}{$4 \mathrm{R}-1,41-45$} & 76.41 & White vein & Dolomite & IV & +1.5 & -10.4 & 70 & 50 & 60 & 280 & $\mathrm{BD}$ & 125,500 & 220,000 \\
\hline & 76.41 & Light brown host & Dolomite & IV & +1.6 & -9.1 & 80 & 50 & 60 & 290 & 100 & 125,800 & 223,000 \\
\hline & 76.41 & Dark brown host & Dolomite & IV & +1.6 & -10.1 & 110 & 50 & 40 & 150 & $\mathrm{BD}$ & 129,600 & 220,000 \\
\hline \multicolumn{14}{|l|}{ Hole 639C: } \\
\hline $2 R-2,65-69$ & 92.95 & Crystals from vug & Dolomite & IV & +1.6 & -10.2 & 50 & 40 & 20 & BD & $\mathrm{BD}$ & 127,400 & 218,000 \\
\hline 2R-2, 89-92 & 93.19 & Host & Dolomite & IV & +2.1 & -7.5 & 120 & 40 & 40 & 270 & $\mathrm{BD}$ & 129,800 & 222,000 \\
\hline \multicolumn{14}{|l|}{ Hole 639D: } \\
\hline $2 \mathrm{R}, \mathrm{CC}(12-15)$ & 187.30 & Host & Dolomite & IV & +1.6 & -10.3 & 100 & 50 & 50 & 220 & $\mathrm{BD}$ & 128,300 & 218,000 \\
\hline $3 R-1,44-48$ & 187.74 & White vein & Dolomite & IV & +1.5 & -10.8 & 50 & 90 & 40 & 710 & 140 & 128,600 & 220,000 \\
\hline $3 \mathrm{R}-1,102-104$ & 188.32 & Host & Dolomite & IV & +1.7 & -7.1 & $\mathrm{BD}$ & 60 & 280 & 400 & 180 & 112,200 & 241,000 \\
\hline 4R-1, 4-9 & 196.84 & Host & Dolomite & IV & +1.7 & -9.9 & 340 & 40 & 30 & 400 & 110 & 126,500 & 220,000 \\
\hline $4 \mathrm{R}, \mathrm{CC}(1-2)$ & 206.41 & Pink host & Calcite & $\mathrm{V}$ & +1.5 & -1.1 & 180 & 60 & 460 & 1040 & 1350 & 3900 & 399,000 \\
\hline \multirow[t]{2}{*}{$5 R-1,93-95$} & 207.43 & Dolomite host & Dolomite & V & +1.8 & -10.2 & 440 & 70 & 70 & 320 & 140 & 126,000 & 220,000 \\
\hline & 207.43 & White vein & Dolomite & $\mathrm{V}$ & +1.5 & -10.3 & $\mathrm{BD}$ & 60 & 80 & 280 & $\mathrm{BD}$ & 128,700 & 228,000 \\
\hline \multirow[t]{2}{*}{$5 \mathrm{R}-2,14-16$} & 208.14 & Host & Calcite & V & +1.6 & -1.5 & 940 & 120 & 160 & 660 & 130 & 3000 & 392,000 \\
\hline & 208.14 & Pink vein crystals & Calcite & $\mathrm{V}$ & +1.4 & -6.4 & 2910 & 220 & $\mathrm{BD}$ & 960 & $\mathrm{BD}$ & 3500 & 383,000 \\
\hline $5 \mathrm{R}-2,141-143$ & 209.41 & White vein & Dolomite & $\mathrm{V}$ & +1.5 & -9.6 & 580 & 140 & 140 & 330 & $\mathrm{BD}$ & 116,000 & 233,000 \\
\hline $6 \mathrm{R}-1,14-17$ & 216.14 & Dolomite host & Dolomite & V & +1.7 & -7.4 & 50 & 50 & 260 & 430 & 140 & 111,000 & 238,000 \\
\hline \multirow[t]{2}{*}{$6 \mathrm{R}-1,38-40$} & 216.38 & Host & Calcite & V & +1.2 & -1.9 & 3100 & 100 & 60 & 680 & $\mathrm{BD}$ & 3100 & 396,000 \\
\hline & 216.38 & Brown vein & Calcite & V & +1.8 & -3.4 & 2670 & 130 & 680 & 1300 & 220 & 1900 & 383,000 \\
\hline \multirow[t]{2}{*}{$7 \mathrm{R}-1,3-4$} & 225.63 & Dolomite host & Dolomite & V & +1.6 & -7.2 & 90 & $\mathrm{BD}$ & 280 & 420 & 160 & 111,600 & 231,000 \\
\hline & 225.63 & White vein & Dolomite & V & +1.5 & -9.8 & $\mathrm{BD}$ & 40 & 190 & 310 & $\mathrm{BD}$ & 116,700 & 245,000 \\
\hline 7R-1, 93-95 & 226.53 & Brown vein & Calcite & V & +2.8 & -2.1 & 400 & 90 & 40 & 470 & 70 & 2100 & 396,000 \\
\hline $8 \mathrm{R}-1,102-104$ & 236.22 & Pink host & Calcite & V & +2.1 & -2.5 & 3790 & 160 & 70 & 360 & 110 & 3000 & 381,000 \\
\hline \multirow[t]{2}{*}{$8 \mathrm{R}, \mathrm{CC}(16-19)$} & 244.90 & Host & Calcite & V & +2.1 & -2.9 & 340 & 100 & 220 & 730 & 140 & 3000 & 392,000 \\
\hline & 244.90 & Clear vein & Calcite & V & +1.8 & -9.9 & 590 & 160 & 270 & 610 & $\mathrm{BD}$ & 3100 & 391,000 \\
\hline \multirow[t]{2}{*}{$10 \mathrm{R}-1,123-126$} & 255.73 & Clear vein & Calcite & V & +1.9 & -12.9 & 870 & 120 & 40 & 390 & 70 & 3100 & 391,000 \\
\hline & 255.73 & Host & Calcite & V & +2.2 & -3.6 & 450 & 100 & 240 & 930 & 190 & 3400 & 391,000 \\
\hline \multirow[t]{2}{*}{$11 \mathrm{R}-2,111-115$} & 266.71 & Host & Calcite & $\mathrm{V}$ & +2.4 & -3.9 & 110 & 120 & 220 & 820 & 120 & 5200 & 368,000 \\
\hline & 266.71 & White vein & Calcite & V & +2.1 & -10.3 & 2170 & 100 & 140 & 580 & 900 & 1400 & 383,000 \\
\hline \multirow[t]{4}{*}{$12 \mathrm{R}-3,4-7$} & 276.83 & Host & Calcite & $\mathrm{V}$ & +2.5 & -4.4 & 2900 & 131 & 40 & 720 & 70 & 4300 & 384,000 \\
\hline & 276.83 & Pink vein & Calcite & V & +2.7 & -12.4 & BD & 100 & 110 & 490 & BD & 3900 & 385,000 \\
\hline & 276.83 & Detrital silt & Dolmite & V & +2.1 & +2.1 & 1090 & 160 & 220 & 220 & 120 & 115,000 & 239,000 \\
\hline & 276.83 & Pink vein & Dolomite & V & +2.7 & -10.4 & 4060 & 140 & 130 & 270 & BD & 114,500 & 240,000 \\
\hline
\end{tabular}

a Lithologic units defined by shipboard sedimentologists. See "Site 639" chapter (Boillot, Winterer, et al., 1987)

${ }^{\mathrm{b}} \mathrm{BD}=$ below detection limit for element.

because of the low iron and manganese contents. This suspicion was reinforced by electron microprobe traverses of individual dolomite rhombohedra from Site 639 (Daniel and Haggerty, this volume) that showed antithetic trends of iron vs. sulfur, as well as manganese vs. sulfur. Ferroan and manganoan carbonates form in reducing environments (Krauskopf, 1967; Hesse, 1986). The decrease in Eh that drives the ferric to ferrous and manganic to manganous transitions may also be responsible for, or related to, the reduction of sulfate to sulfide (Hesse, 1986). Baker and Burns (1985) showed that iron- and manganese-rich dolomites form from sulfate-depleted waters. Gas analysis of individual fluid inclusions and dolomite pyrolysis mass spectrometry were used to test the oxidation state of the sulfur and to determine the mode of incorporation of the sulfur in the Galicia margin dolomite.

The gas contents of the fluid inclusions from the Galicia margin dolomite lack detectable amounts of hydrocarbons. These fluid inclusions are typically characterized as water dominated, containing appreciable carbon dioxide, and displaying a minor peak at mass/charge ratio (atomic mass unit $=\mathrm{AMU}$ ) of 48 that we interpret as an $\mathrm{SO}^{+}$ionization fragment (Fig. 2). The intensity of the $\mathrm{SO}^{+}$fragment is only about $0.012 \%$ of the main water fragment at AMU of 18 . The $\mathrm{SO}^{+}$fragment is most likely derived from either $\mathrm{SO}_{2}$ or $\mathrm{SO}_{4}$. We have observed a similar 


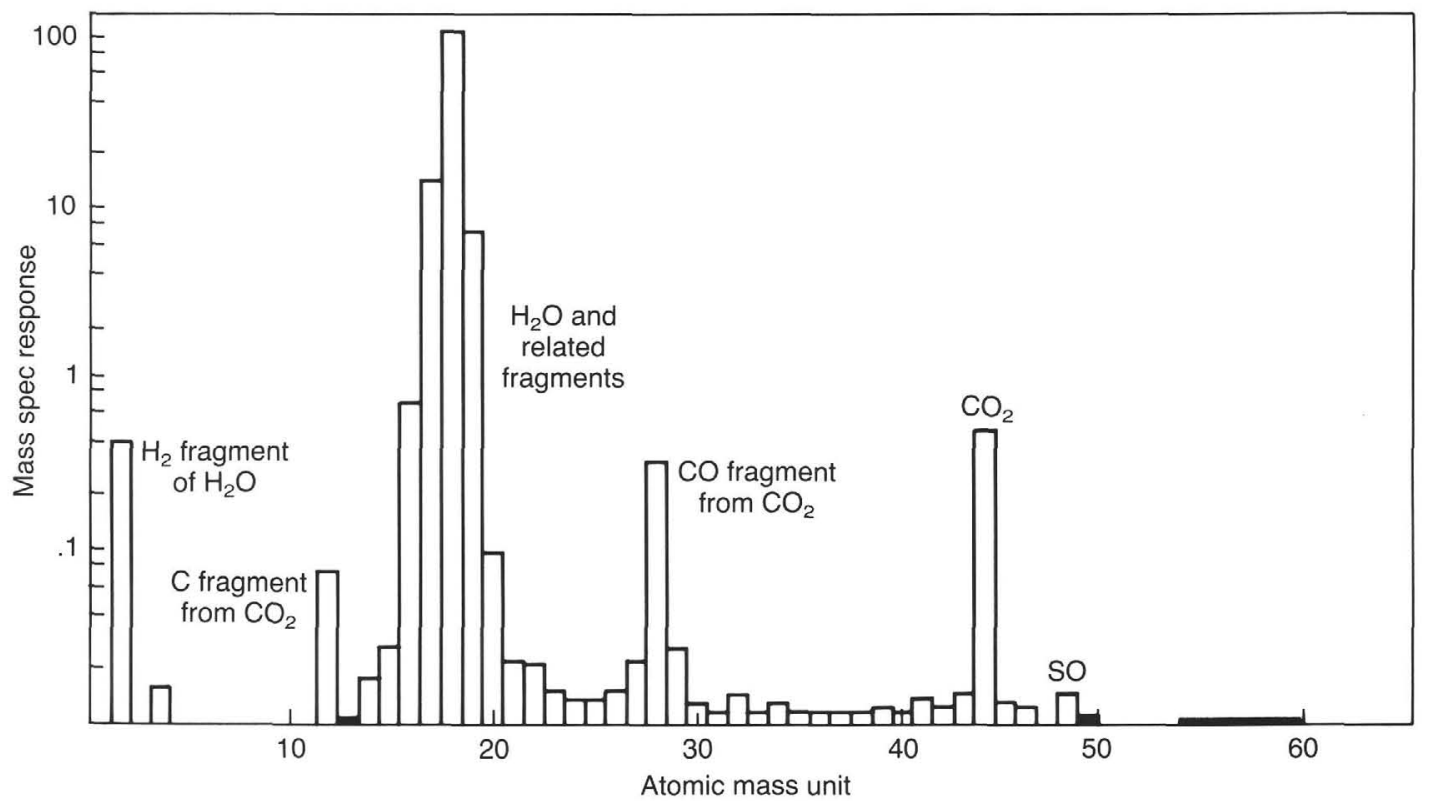

Figure 2. Typical fluid inclusion mass spectrum obtained using the technique of Barker and Smith (1986). Sample 103639A-8R, CC $(6-11 \mathrm{~cm})$.

peak at AMU of 48 in analyses of fluid inclusions in cements from modern beach rocks and in modern ooids. These inclusions contain either normal or nearly normal seawater, and the most plausible explanation of their response at AMU of 48 is attributable to $\mathrm{SO}^{+}$derived from dissolved sulfate in seawater. We have analyzed numerous inclusions that contain reduced sulfur gas in the form of $\mathrm{H}_{2} \mathrm{~S}$, and these samples do not show a response at AMU of 48. The presence of an oxidized sulfur gas species and the absence of appreciable hydrocarbons in the Galicia margin dolomite indicate that the fluid inclusions trapped relatively oxidizing fluids.

In addition to analysis of volatile contents of fluid inclusions, the dolomite samples were vacuum pyrolyzed to check for the presence of sulfate. The sulfur concentration in the dolomite and limestone is too low for determination of the sulfur valence state using the electron microprobe. Upon vacuum pyrolysis, sulfates decompose and produce sulfur dioxide; sulfides do not evolve sulfur dioxide upon heating in vacuum. Mass spectrometric analyses of the evolved gases show that sulfur in the dolomite samples is present as sulfate. The presence of sulfate in the Galicia margin dolomite, as well as the low iron and manganese content (Table 1), indicates formation from oxidizing, sulfate-bearing solutions. This conclusion does not depend on the mode of incorporation of sulfate in the dolomite.

During shallow burial, decrease of Eh in the pore water mobilizes manganese, and further reduction mobilizes iron from the sediments (Hesse, 1986). The low iron and manganese contents, the generation of sulfur dioxide during pyrolysis, and the oxidized nature of the fluid inclusion gases indicate that the Galicia margin dolomite formed at relatively high Eh. With the exception of euxinic basins, oxidizing conditions exist at the sediment/water interface to shallow sub-bottom depths associated with the zone of bioturbation where molecular oxygen is present. Shallow burial results in the subsequent reduction of nitrate, manganese, iron, sulfate, and carbonate. Oxidizing conditions at depth require active circulation from the sediment/water interface. Downward migration of oxidizing fluids can occur along faults and fractures and through open pore systems if a density inversion exists.

Relatively oxidizing, deep basinal, sulfate-bearing brines may be formed by the dissolution of evaporites at depth. Brines formed in this manner will have calcium greatly in excess of magnesium, because subsurface sulfates are dominated by anhydrite and contain only very minor amounts of magnesium sulfates (Borchert and Muir, 1964). The only common magnesiumrich fluids in the hydrosphere are seawater and its derivatives (Land, 1985), such as magnesium-rich, sulfate-bearing brines. Calcium-rich, magnesium-poor, sulfate-bearing, deep basinal brines are not considered to be a dolomitizing agent because of insufficient magnesium. Our data, and the need for a magnesium source, are best explained by the dolomitizing fluid being seawater or one of its derivatives. Therefore, the dolomitization of the Galicia carbonate platform occurred either at shallow sub-bottom depths or as the result of downward percolation of dense oxidizing brines.

\section{Sulfate Mineral Inclusions}

During dolomite pyrolysis, the release of sulfur dioxide displays a distinct temperature dependence that is characteristic of the decomposition of physical mixtures of various sulfate minerals. Table 2 lists the presence or absence of sulfate minerals determined by dolomite pyrolysis mass spectrometry. These analyses show the presence of trace quantities of hypersaline sulfate minerals that have not been observed in dolomites by other techniques. Most of the dolomite samples show sodium magnesium sulfates and either anhydrite or celestite.

Critical to the interpretation of these data is the source and mode of incorporation of the sulfate minerals identified from pyrolysis. The source of the sulfur dioxide does not appear to be sulfate substitution into the dolomite lattice. For example, sulfur dioxide is evolved with carbon dioxide between $500^{\circ}$ and $700^{\circ} \mathrm{C}$ upon decomposition of calcium carbonate during pyrolysis of a barnacle shell that contains as much as 10,000 ppm sulfate in solid solution with the carbonate (Smith, unpubl. data). Substitution of sulfate into carbonate lattice positions yields the simultaneous release of sulfur dioxide and carbon dioxide upon destruction of the carbonate structure during pyrolysis. Sulfur dioxide is released from the Galicia margin dolomite at elevated temperatures, in excess of $900^{\circ} \mathrm{C}$, without the simultaneous evolution of carbon dioxide. Carbon dioxide is evolved from the decomposition of the dolomite structure at a lower temperature range of $500^{\circ}-700^{\circ} \mathrm{C}$, but without the release of sulfur dioxide. 
Table 2. Dolomite pyrolysis mass spectrum results. $X=$ mineral present; $V L=$ very low release during pyrolysis; $-=$ mineral not detected.

\begin{tabular}{|c|c|c|c|c|}
\hline $\begin{array}{c}\text { Sample } \\
\text { interval }(\mathrm{cm})\end{array}$ & Description & $\mathrm{SrSO}_{4}$ & $\mathrm{CaSO}_{4}$ & NaMg-sulfate \\
\hline \multicolumn{5}{|l|}{ Hole 639A: } \\
\hline $8 \mathrm{R}, \mathrm{CC}(6-11)$ & Host & $\mathrm{x}$ & - & $\mathrm{x}$ \\
\hline $9 \mathrm{R}-1,11-15$ & Host & $\mathrm{x}$ & - & - \\
\hline $9 \mathrm{R}-1,87-90$ & Host & $\mathrm{x}$ & - & $\mathrm{VL}$ \\
\hline \multirow{2}{*}{$9 \mathrm{R}-1,94-98$} & White vein & $\mathrm{x}$ & $\mathrm{X}$ & $\mathrm{x}$ \\
\hline & Host & - & $\mathrm{X}$ & $\mathrm{X}$ \\
\hline $10 \mathrm{R}-1,32-35$ & Host & - & $\mathrm{x}$ & - \\
\hline $10 \mathrm{R}-1,47-49$ & Host & $\mathrm{x}$ & - & $\mathrm{X}$ \\
\hline \multirow{4}{*}{$10 \mathrm{R}-2,16-19$} & Detrital silt & $\mathrm{x}$ & $\mathrm{x}$ & $\mathrm{x}$ \\
\hline & Dark brown infill & $\mathrm{x}$ & $\mathrm{x}$ & $\mathrm{X}$ \\
\hline & Host & $\mathrm{x}$ & $\mathrm{x}$ & - \\
\hline & White vein & - & - & VL \\
\hline $10 \mathrm{R}-2,48-50$ & Host & $\mathrm{X}$ & $\mathrm{X}$ & $\mathrm{X}$ \\
\hline \multicolumn{5}{|l|}{ Hole 639B: } \\
\hline $2 \mathrm{R}-1,35-37$ & Dark brown host & $\mathrm{x}$ & $\mathrm{x}$ & $\mathrm{x}$ \\
\hline \multirow[t]{2}{*}{$3 \mathrm{R}-1,46-51$} & Brown sugary crystals & - & - & $\mathrm{x}$ \\
\hline & Dark brown host & - & $\mathrm{x}$ & $\mathrm{x}$ \\
\hline $3 R, C C(0-4)$ & Vein & - & $\mathrm{X}$ & $\mathrm{X}$ \\
\hline $4 \mathrm{R}-1,35-37$ & Light brown crystals from vug & - & $\mathrm{x}$ & - \\
\hline \multirow[t]{3}{*}{$4 \mathrm{R}-1,41-45$} & White vein & - & VL & VL \\
\hline & Light brown host & $\mathrm{X}$ & - & - \\
\hline & Dark brown host & $\mathrm{x}$ & - & - \\
\hline \multicolumn{5}{|l|}{ Hole 639C: } \\
\hline $2 \mathrm{R}-2,65-59$ & Crystals from vug & - & $\mathrm{x}$ & - \\
\hline $2 \mathrm{R}-2,89-92$ & Host & - & $\mathrm{x}$ & $\mathrm{x}$ \\
\hline \multicolumn{5}{|l|}{ Hole 639D: } \\
\hline $2 \mathrm{R}, \mathrm{CC}(12-15)$ & Host & $\mathrm{x}$ & $\mathrm{X}$ & - \\
\hline \multirow{2}{*}{$3 \mathrm{R}-1,44-48$} & White vein & - & - & VL \\
\hline & Host & $\mathrm{x}$ & - & $\mathrm{X}$ \\
\hline $3 R-1,102-104$ & Host & $\mathrm{x}$ & - & - \\
\hline $4 \mathrm{R}-1,4-9$ & Host & - & $\mathrm{x}$ & - \\
\hline $5 \mathrm{R}-1,93-95$ & Host & - & - & $\mathrm{x}$ \\
\hline $6 \mathrm{R}-1,14-17$ & Host & - & $\mathrm{x}$ & $\mathrm{X}$ \\
\hline $7 \mathrm{R}-1,3-4$ & Host & - & - & $\mathrm{x}$ \\
\hline
\end{tabular}

Furthermore, the pattern of sulfur dioxide released from these dolomites during pyrolysis is highly variable, which would not be expected if the sulfate was present as a solid solution for carbonate.

We attempted to eliminate evaporated pore fluids as a potential source of sulfate. The washing procedure should have been sufficient to remove any sulfates formed by evaporation of pore fluids. Sulfate minerals that evaporate from saline fluids are highly soluble in fresh water, and in this regard, it should be noted that some of the samples were washed for more than 3 days without noticeable effect on their sulfur dioxide release pattern. Numerous mid-continent outcrop samples of dolomite evolve sulfur dioxide in patterns similar to those observed in the Galicia margin dolomite (Smith, unpubl. data), and it is unlikely that the sulfur dioxide released from these dolomites is from evaporated pore fluids. In addition, the sulfur dioxide released from many of the samples is dominated by celestite, Srsulfate. Simple evaporation of pore fluids, or of fluid inclusions, does not result in a celestite-dominated sulfur dioxide release pattern during pyrolysis because $\mathrm{Sr}$ is not the major cation in natural waters (Collins, 1975).

As mentioned previously, the apparent predominance of sulfur dioxide released from celestite in many of the pyrolysis experiments suggests that trace sulfate minerals are not exclusively derived from decrepitated fluid inclusions. This inference is further supported by the great variety of sulfur dioxide pyrolysis patterns (Fig. 3). Many of these dolomite pyrograms show the same peaks in each sample, but the ratio of the peaks differs significantly (see Fig. 3). This extreme variability in sulfur dioxide release patterns suggests that sulfate occurs in the dolomites as physical mixtures of multiple sources. Fluid inclusion petrography revealed only scarce primary fluid inclusions of nearly uniform size and homogenization temperatures. The uniformity in size and homogenization behavior suggests that the fluid inclusions have a limited range of composition. It is unlikely that the variety of observed pyrolysis patterns was generated solely or predominantly from residues of these fluid inclusions.

The extreme variability of the sulfur dioxide release patterns, along with the predominance of sulfur dioxide release at the characteristic temperature for celestite in many samples, is most easily explained by the random entrapment of solid, sulfate mineral microinclusions in the dolomite. Electron microprobe analyses provide additional evidence for the presence of solid, sulfate mineral inclusions. The strontium concentration in many of the dolomite samples is in excess of $300 \mathrm{ppm}$ and as high as $750 \mathrm{ppm}$ (Table 1). Bein and Land (1983) interpret strontium in excess of $200 \mathrm{ppm}$ in the San Andres Dolomite as evidence for solid celestite microinclusions. Moreover, electron microprobe traverses of individual dolomite rhombohedra from Site 639 samples show strontium concentrations as high as $1500 \mathrm{ppm}$ (Daniel and Haggerty, this volume). Electron microprobe traverses also showed the distribution of strontium, as well as sodium and sulfur, to be extremely variable on a micron scale. The complete concentration range for these three elements can be found within $3 \mu \mathrm{m}$ in various parts of the dolomite. This extreme variability, as well as the high strontium concentrations, 


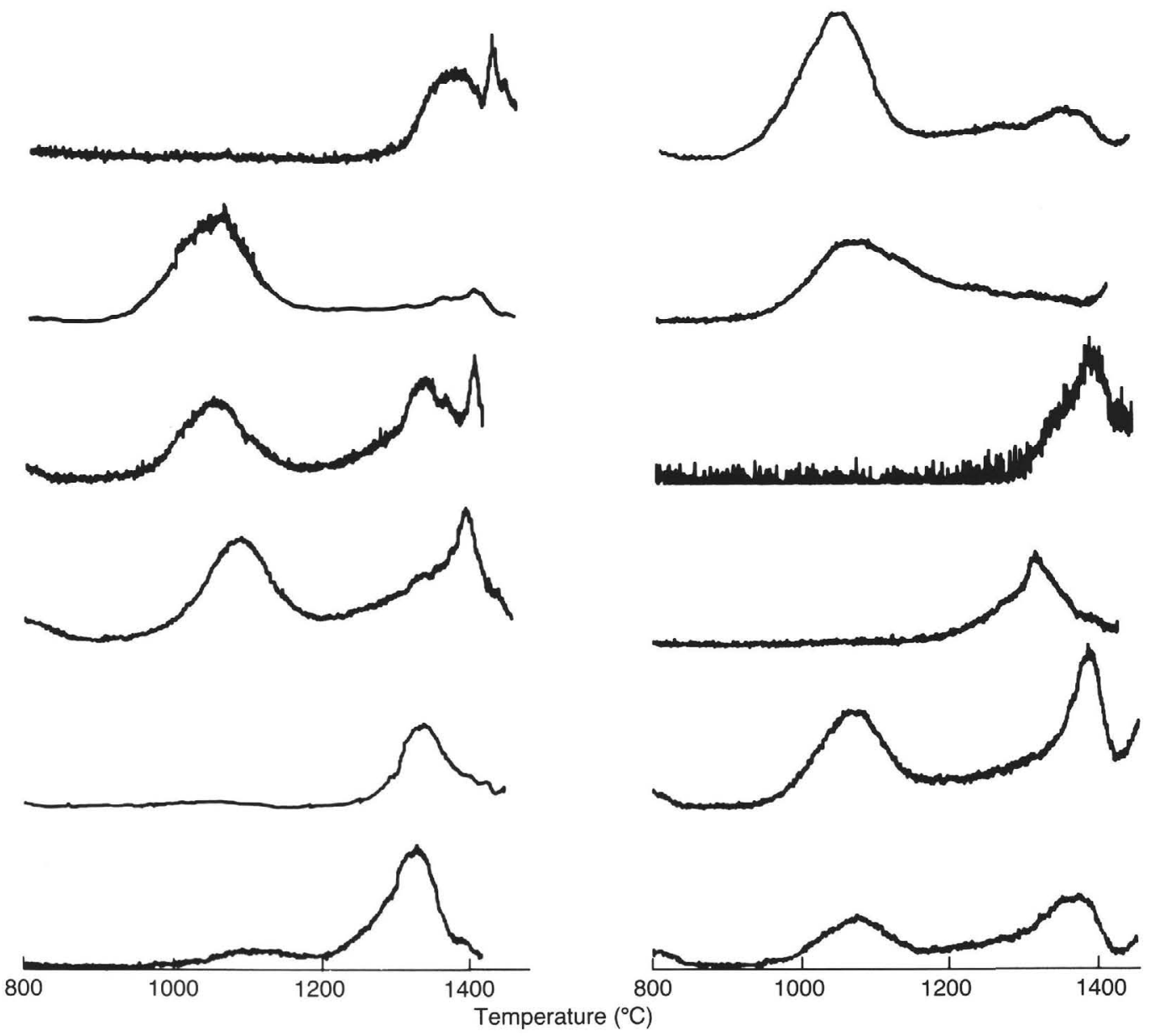

Figure 3. Dolomite pyrograms showing sulfur dioxide release patterns as a function of temperature. Peaks are the same as labeled in Figure 4. Note the variety of sulfur dioxide release patterns, suggesting that sulfate in the dolomite is present as solid microinclusions of sulfate minerals.

can be most easily explained as the result of solid inclusions.

The abundance of strontium in the Galicia margin dolomite can not be explained as the result of fluid inclusions. The results of the electron microprobe analyses indicate that the volume being analyzed is almost exclusively dolomite, with only trace contributions from other sources. If $1 \%$ of the analyzed volume consisted of fluid inclusions and if this was the only source of the analyzed $1500 \mathrm{ppm} \mathrm{Sr}$, then the inclusions would have to contain as much as 150,000 ppm Sr, which is unlikely for any natural waters. Strontium-rich subsurface brines contain up to $3500 \mathrm{mg} / \mathrm{L} \mathrm{Sr}$, roughly $3500 \mathrm{ppm} \mathrm{Sr}$ (Collins, 1975); therefore, the most strontium-rich, naturally occurring brines would have to constitute $42 \%$ of the analyzed volume in order to obtain a microprobe analysis of $1500 \mathrm{ppm}$ Sr. This argument is also applicable to fluid inclusions that have been decrepitated. Because celestite contains more than $470,000 \mathrm{ppm} \mathrm{Sr}$, an analysis of 1500 ppm Sr would correspond to only $0.3 \%$ celestite as solid inclusions in the analyzed volume. Furthermore, it should be noted that other workers, especially Beales and Hardy (1980) and Bein and Land (1983), have documented the presence of trace sulfate mineral inclusions in dolomites by other nonroutine and nonpetrographic techniques and have interpreted their results as evidence for dolomitization by hypersaline brines.

Sulfur dioxide evolution during pyrolysis of the Galicia margin dolomite generally shows a trimodal distribution as a function of temperature (Fig. 4). A low-temperature peak between $1000^{\circ}$ and $1200^{\circ} \mathrm{C}$, seen more distinctly in Figure $4 \mathrm{~A}$, corresponds to the thermal decomposition of a variety of $\mathrm{Na}-, \mathrm{Mg}-$, and $\mathrm{NaMg}$-sulfates; the peak about $1300^{\circ} \mathrm{C}$, seen more distinctly in Figure 4B, corresponds to Ca-sulfate (gypsum and anhydrite); and the peak about $1400^{\circ} \mathrm{C}$, seen more distinctly in Figure 4A, corresponds to celestite (Smith, unpubl. data). Some of the dolomites display all three peaks in various proportions (Fig. 4), others have two of the three, and still others have only one (see Table 2 and Fig. 3). This is most easily explained by considering all of the peaks as resulting from the decomposition of inclusions consisting of solid, sulfate minerals, rather than from residues of fluid inclusions.

These three sulfate minerals are commonly associated with marine evaporites. The NaMg-sulfates are diagnostic of extremely hypersaline environments and indicate formation from a marine brine that had evolved to a late halite facies (Stewart, 1963).

\section{Fluid Inclusion Microthermometry}

Fluid inclusion microthermometry was used to confirm the inferred hypersaline nature of the dolomitizing fluid. Fluid inclusions in the Galicia margin dolomite are sparse and difficult to locate, typically small ( 5 to $10 \mu \mathrm{m}$ ), and occur in an apparently random distribution. These attributes suggest that the inclusions are of primary origin (Roedder, 1984; Shepherd et al., 1985).

Table 3 lists homogenization temperatures determined by heating fluid inclusions. The dolomites were recovered from depths of less than $300 \mathrm{~m}$ below seafloor. Although it is possible that these dolomites were more deeply buried in the past, no pressure correction was applied to the homogenization temperatures. Ho- 

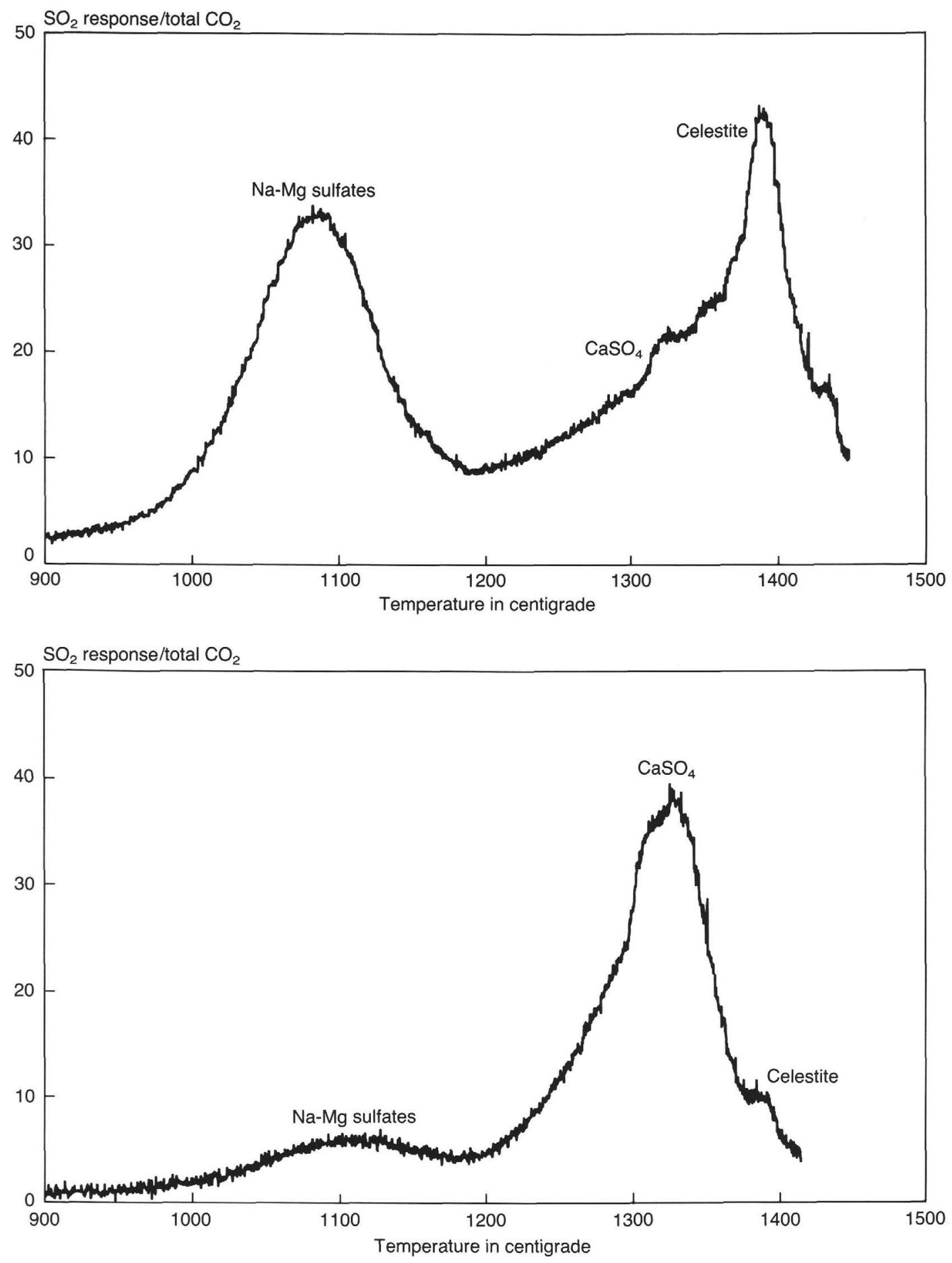

Figure 4. Typical patterns of sulfur dioxide released during dolomite pyrolysis. Peaks diagnostic of specific sulfate minerals occur at characteristic temperatures. Vertical axis is sulfur dioxide response of the mass spectrometer relative to total amount of carbon dioxide released; scale is arbitrary. Horizontal axis is temperature during pyrolysis in degrees centigrade. See text for discussion. A. NaMg-sulfates- and celestite-dominated sulfur dioxide release pattern. Sample 103-639A-10R-1, 47-49 cm. B. Calcium sulfate-dominated sulfur dioxide release pattern. Sample 103639A-9R-1, 94-98 cm.

mogenization temperatures of dolomite range from $67^{\circ}$ to $84^{\circ} \mathrm{C}$ (Fig. 5). These temperatures are elevated for shallow-burial depths and typical sabkha environments $\left(30^{\circ} \mathrm{C} \pm 5^{\circ} \mathrm{C}\right.$; McKenzie et al., 1980) and are slightly elevated compared to bottom-water temperatures of $57^{\circ} \mathrm{C}$ for Solar Lake (Aharon et al., 1977). The moderately high temperatures indicated by the fluid inclusions probably reflect, in part, the initial anomalously high geothermal gradients associated with the rifting of the margin and/or some reequilibration of the inclusions by burial heating (Burruss, 1987). Burial heating can easily cause errors of $10^{\circ}$ to $20^{\circ} \mathrm{C}$ or more in the homogenization temperatures, thereby indicating misleading higher initial trapping temperatures (Burruss, 1987).

\section{Stable Isotope Geochemistry}

The positive carbon isotopic compositions of the calcite and dolomite (Table 1 ) are consistent with a marine source. The very 
Table 3. Homogenization temperatures of fluid inclusions from Site 639 samples. Multiple homogenization temperatures associated with the same sample number result from analyzing multiple fluid inclusions in that sample.

\begin{tabular}{|c|c|c|c|}
\hline $\begin{array}{c}\text { Sample } \\
\text { interval }(\mathrm{cm})\end{array}$ & Description & Mineralogy & $\begin{array}{c}\text { Homogenization } \\
\text { temperatures } \\
\qquad\left({ }^{\circ} \mathrm{C}\right)\end{array}$ \\
\hline \multicolumn{4}{|l|}{ Hole 639A: } \\
\hline 9R-1, 94-98 & Host & Dolomite & $\begin{array}{l}73 \\
77\end{array}$ \\
\hline 10R-1, 47-49 & Host & Dolomite & $\begin{array}{l}73 \\
74 \\
80 \\
84\end{array}$ \\
\hline $10 \mathrm{R}-2,48-50$ & Host & Dolomite & $\begin{array}{l}67 \\
74 \\
76 \\
77 \\
77 \\
80 \\
80 \\
81 \\
81 \\
82 \\
84\end{array}$ \\
\hline \multicolumn{4}{|l|}{ Hole 639B: } \\
\hline $4 \mathrm{R}-1,35-37$ & $\begin{array}{l}\text { Light brown } \\
\text { crystals from } \\
\text { vug }\end{array}$ & Dolomite & $\begin{array}{l}68 \\
77\end{array}$ \\
\hline \multicolumn{4}{|l|}{ Hole 639D: } \\
\hline $3 R-1,102-104$ & Host & Dolomite & $\begin{array}{l}72 \\
73 \\
77 \\
77 \\
78\end{array}$ \\
\hline $10 \mathrm{R}-1,123-126$ & Clear vein & Calcite & $\begin{array}{r}77 \\
88 \\
100\end{array}$ \\
\hline
\end{tabular}

light oxygen isotopic composition of the dolomite (Table 1) is typically interpreted to indicate an association with fresh water or hydrothermal activity (Mattes and Mountjoy, 1980). However, the preceding geochemical results indicate that the initial dolomitizing event occurred in the presence of oxidizing, hypersaline brines.

During evaporation of seawater in a humid environment, the oxygen isotopic composition of the seawater initially becomes heavier, later reversing to lighter compositions (Holser, 1979; Pierre et al., 1984; Knauth and Beeunas, 1986). A consistent interpretation of the isotopic and geochemical data can be made on the basis of the "evaporative loop" model. Bein and Land (1983) argued that the relatively light oxygen isotopic composition of the San Andres Dolomite resulted from precipitation in isotopically light evaporated seawater. Bein and Land (1983) also presented other evidence indicating that evaporation never proceeded beyond halite facies to the precipitation of $\mathrm{NaMg}$ sulfates and other bittern salts. This is confirmed by dolomite pyrolysis mass spectrometry of San Andres Dolomite, which reveals trace amounts of celestite and possibly calcium sulfate but no NaMg-sulfates (Smith, unpubl. data), with the isotopically lightest dolomite about - $1 \%$ PDB. If the "evaporative loop" is to completely explain the exceptionally light oxygen isotopes in this study, then it is necessary to invoke either enhanced evaporation of seawater and/or higher initial temperatures during dolomite formation.

Results from pyrolysis mass spectrometry of the Galicia dolomite indicate brine evolution to saturation with $\mathrm{NaMg}$-sulfates. Fluid inclusion microthermometry indicates that dolomit-

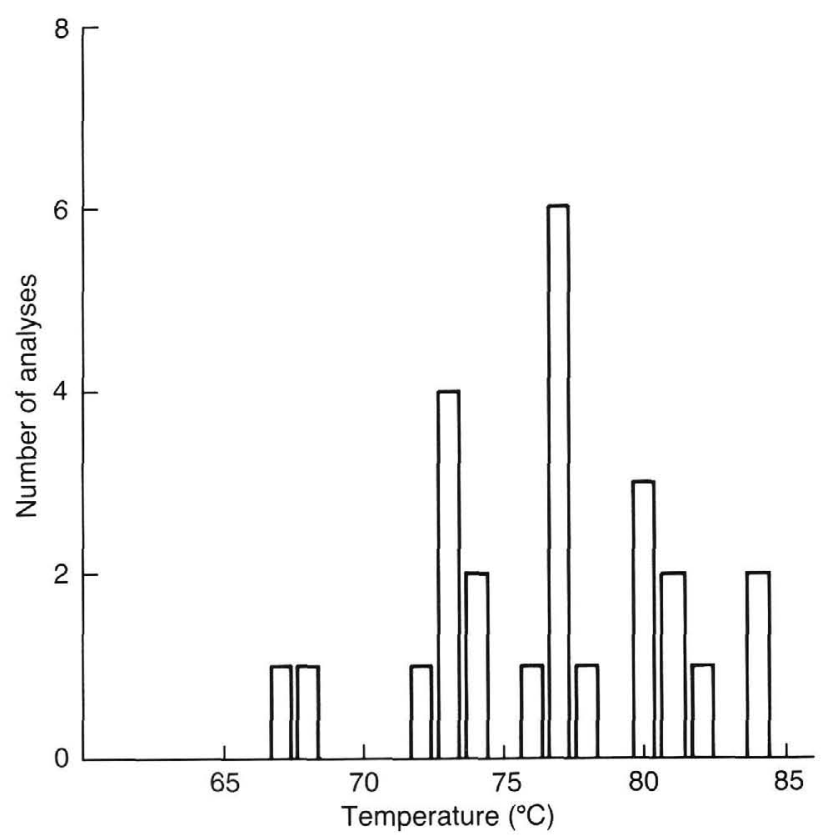

Figure 5. Histogram of dolomite fluid inclusion homogenization temperatures for samples from Holes 639A-639D. Data listed in Table 3.

ization may have occurred at elevated temperatures. Both of these factors would result in an isotopically lighter dolomite.

The oxygen isotopic composition of the dolomitizing fluid can be estimated from the isotopic composition of the dolomites and the temperature of homogenization of the fluid inclusions. Using the equations summarized in Bein and Land (1983), an average dolomite oxygen isotopic composition of $-10 \% 0$ PDB and a temperature of $78^{\circ} \mathrm{C}$ result in a calculated oxygen isotopic composition of seawater of $-2 \%$ SMOW. This corresponds to seawater concentrated to about 45 times (Knauth and Beeunas, 1986). The calculated water isotopic composition is within the range of halite fluid-inclusion waters analyzed by Knauth and Beeunas (1986). This estimated seawater concentration falls within the range of magnesium sulfate precipitation determined in Usiglio's (1849) seawater evaporation experiments at room temperature. An initial dolomite formation associated with hypersaline fluids is consistent with all of the data presented in this paper. A diagenetic overprint may have occurred after the initial dolomitization of the Galicia platform carbonates during deeper burial, causing reequilibration of the fluid inclusions and the oxygen isotopic composition of the dolomite. Thus, the degree of hypersalinity and temperature constraints during the initial dolomitization could be relaxed from the preceding discussion.

\section{Environment of Dolomitization}

The carbonate platform dolomite is in the upper stratigraphic part, underlain by limestone (Fig. 1). If the carbonate platform were hydrothermally dolomitized by brines from below, then one would expect limestone overlying dolomite rather than the observed sequence. The geochemistry of hydrothermal systems associated with oceanic rifts (Galapagos, the East Pacific Rise $21^{\circ} \mathrm{N}$ ) and Iceland (Reykjanes Peninsula) are summarized by Holland $(1978,1984)$. These hydrothermal brines have essentially no magnesium or sulfate, and they contain considerable amounts of iron, manganese, and hydrogen sulfide. In comparison to seawater, these fluids are chemically reduced. Not only were reduced species, such as hydrogen sulfide, not observed in the Galicia dolomites, but instead, our analyses document the presence of oxidized volatiles and solids as inclusions within the Galicia dolomite. 
According to Land (1985), less than 10 pore volumes of seawater evaporated to saturation with bittern salts is necessary to dolomitize limestone. From the pyrolysis results, the brine associated with initial dolomitization of the Galicia platform evolved to saturation with NaMg-sulfates. The inferred dense, magnesium-rich brine is therefore hydrologically attractive. In contrast, 30,800 , and 6500 pore volumes of halite-saturated seawater, normal seawater, and seawater diluted by 10 times with meteoric water, respectively, are required to provide sufficient magnesium to dolomitize limestone. The observed stratigraphic sequence of dolomite overlying limestone would be predicted as a result of the infiltration and migration of dense, oxidized, sulfate-bearing hypersaline brines down from the surface or fed laterally through the strata from a nearby surficial source. Downward migration would also have been facilitated by fluid flow along faults and fractures.

\section{CONCLUSIONS}

The main conclusion of this research is that the initial dolomitizing fluid was hypersaline. Light oxygen isotopic signatures of dolomite are interpreted as resulting either from the evaporative loop and slightly elevated temperatures during formation of the dolomite or by reequilibration at higher, deeper burial temperatures. The hypersalinity is interpreted to be associated with a nearby, shallow restricted basin that formed during rifting of the Iberian margin from Newfoundland. No massive deposits of evaporite minerals were recovered from this site or any other site drilled during this leg; the contact between the Valanginian marlstone (Unit III) and the dolomite (Unit IV) was also not recovered. From the lithologic evidence of argillaceous sediment containing detrital dolomite silt infilling some of the fractures in both Units IV and V and the isotopic composition of the sediments, the interpretation is made that the upper part of the fault block underwent a period of marine exposure, during which the more soluble evaporite minerals could have been removed.

The initial dolomitization of the platform is therefore a byproduct of the rifting. Tilting or uplift of the fault block may have generated a nearby restricted basin that formed hypersaline brines. A higher geothermal gradient probably existed immediately prior to and associated with rifting of the margin, and faulting and fracturing of the strata associated with rifting opened conduits through which hypersaline brines could dolomitize the strata.

\section{ACKNOWLEDGMENTS}

J. A. Haggerty thanks the Ocean Drilling Program for inviting her to participate on Leg 103. M. P. Smith thanks Amoco Production Company for permission to publish these results. The authors thank the two anonymous reviewers, provided by ODP, for comments on a previous version of this manuscript. This research was supported by a grant from the JOI-U.S. Science Advisory Committee.

\section{REFERENCES}

Aharon, P., Kolodny, Y., and Sass, E., 1977. Recent hot brine dolomitization in the "Solar Lake," Gulf of Elat, isotopic, chemical, and mineralogical study. J. Geol., 85:27-48.

Baker, P. A., and Burns, S. J., 1985. Occurrence and formation of dolomite in organic-rich continental margin sediments. AAPG Bull., 69: 1917-1930.

Barker, C., and Smith, M. P., 1986. Mass spectrometric determination of gases in individual fluid inclusions in natural minerals. Anal. Chem., 58:1330-1333.
Beales, F. W., and Hardy, J. L., 1980. Criteria for the recognition of diverse dolomite types with an emphasis on studies on host rocks for Mississippi Valley-type ore deposits. In Zenger, D. H., Dunham J. B., and Ethington, R. L. (Eds.), Concepts and Models of Dolomitization: Spec. Publ. Soc. Econ. Paleontol. Mineral., 28:197-213.

Bein, A., and Land, L. S., 1983. Carbonate sedimentation and diagenesis associated with $\mathrm{Mg}$-Ca-chloride brines: the Permian San Andres Formation in the Texas Panhandle. J. Sediment. Petrol., 53:243-260.

Boillot, G., Winterer, E. L., et al., 1987. Proc. ODP, Init. Repts., 103: College Station, TX (Ocean Drilling Program).

Borchert, H., and Muir, R. O., 1964. Salt Deposits: The Origin, Metamorphism, and Deformation of Evaporites: New York (Van Nostrand).

Burruss, R. C., 1987. Diagenetic paleotemperatures from aqueous fluid inclusions: re-equilibration of inclusions in carbonate cements by burial heating. Mineral. Mag., 51:477-481.

Collins, A. G., 1975. Geochemistry of Oilfield Waters: New York (Elsevier).

Hesse, R., 1986. Diagenesis \#11. Early diagenetic pore water/sediment interaction: modern offshore basins. Geosci. Can., 13:165-195.

Holland, H. D., 1978. The Chemistry of the Atmosphere and Oceans: New York (Wiley).

1984. The Chemical Evolution of the Atmosphere and Oceans: Princeton, NJ (Princeton Univ. Press).

Holser, W., 1979. Trace elements and isotopes in evaporites. Rev. Mineral., 6:295-346.

Knauth, L. P., and Beeunas, M. A., 1986. Isotope geochemistry of fluid inclusions in Permian halite with implications for the isotope history of ocean water and the origin of saline formation waters. Geochim. Cosmochim. Acta, 50:419-433.

Krauskopf, K. B., 1967. Introduction to Geochemistry: New York (McGraw-Hill).

Land, L. S., 1985. The origin of massive dolomite. J. Geol. Educ., 33: 112-125.

Mattes, B. W., and Mountjoy, E. W., 1980. Burial dolomitization of the Upper Devonian Miette buildup, Jasper National Park, Alberta. In Zenger, D. H., Dunham J. B., and Ethington, R. L. (Eds.), Concepts and Models of Dolomitization: Spec. Publ. Soc. Econ. Paleontol. Mineral., 28:259-297.

McCrea, J. M., 1950. On the isotopic chemistry of carbonates and a paleotemperature scale. J. Chem. Phys., 18:849-857.

McKenzie, J. A., Hsü, K. J., and Schneider, J. F., 1980. Movement of subsurface waters under the sabkha, Abu Dhabi, UAE, and its relation to evaporative dolomite genesis. In Zenger, D. H., Dunham J. B., and Ethington, R. L. (Eds.), Concepts and Models of Dolomitization: Spec. Publ. Soc. Econ. Paleontol. Mineral., 28:11-30.

Pierre, C., Ortlieb, L., and Person, A., 1984. Supratidal evaporitic dolomite at Ojo de Liebre lagoon: mineralogical and isotopic arguments for primary crystallization. J. Sediment. Petrol., 54:1049-1061.

Roedder, E., 1984. Fluid inclusions. Rev. Mineral., 12.

Shepherd, T., Rankin, A. H., and Alderton, D.H.M., 1985. A Practical Guide to Fluid Inclusion Studies: New York (Chapman and Hall).

Smith, M. P., 1986. Silver coating inhibits electron beam damage of carbonates. J. Sediment. Petrol., 56:560-561.

Stewart, F. H., 1963. Marine evaporites. In Fleischer, M. (Ed.), Data of Geochemistry: Geol. Surv. Prof. Pap. (U.S.), 440-Y:1-53.

Usiglio, J., 1849. Analyse de l'eau de la Méditerranée sur les côtes de France. Ann. Chim. (Paris), 27:92-107 and 172-191.

Veizer, J., 1983. Chemical diagenesis of carbonates: theory and application of trace element technique. In Arthur, M., Anderson, T. F., Kaplan, I. R., Land, L. S., and Veizer, J., Stable Isotopes in Sedimentary Geology: SEPM Short Course, 10:3-1-3-100.

Weber, J. N., 1964. Trace element compositions of dolostones and dolomites and its bearing on the dolomite problem. Geochim. Cosmochim. Acta, 28:1817-1868.

Date of initial receipt: 14 May 1987

Date of acceptance: 5 May 1988

Ms 103B-155 